\title{
The Effect Of Entrepreneurial Orientation And Creativity On The Development Of Small Business Credit Union Members On The Cu Lanamona, Maliana Timor Leste
}

\author{
Jacinta Dos Santos ${ }^{1}$, Endang Eveline Giri ${ }^{2}$; Augusto da Conceição Soares ${ }^{3}$ \\ Master's Programa, Institute of Business (IOB), Timor Leste ${ }^{1}$ \\ Faculty of Communication, UNDANA University, Kupang - Indonesia ${ }^{2}$ \\ Master's Program, Institute of Business (IOB), Timor Leste ${ }^{3}$
}

\begin{abstract}
This study aims to analyze and explain; (1) The effect of entrepreneurial orientation on the development of small businesses of members of Lanamona; (2) The effect of creativity on the development of small businesses of members of Lanamona. The population in this study was 130 members of CU Lanamona engaged in small business, in the municipality of Bobonaro. Of this total collected all questionnaires distributed. The data analysis method uses SPSS. The findings of this study are that the entrepreneurial orientation variable has a positive and partially significant effect on the development of small businesses. This is evidenced by the value of $t$-count 2.775 greater than $\mathrm{t}$-table 1.97810. These results suggest that entrepreneurial orientation is a factor that plays an important role in determining the level of improvement of small business development. The higher entrepreneurial orientation, will encourage the higher development of small businesses. Conversely, if entrepreneurship orientation is low, business development will also experience a decline. The variable of creativity has a positive and partially significant effect on the development of small businesses. Therefore, the higher the creativity that is carried out by entrepreneurs, the business development will increase. This is evidenced by the value of $t$-count (3.857) is greater than $\mathrm{t}$-table (1.97810). Entrepreneurial orientation and creativity variables simultaneously have a positive and significant effect on the development of small businesses. This is evidenced by the calculated F-count $(32,746)$ greater than $\mathrm{F}_{\text {-table }}$ (3.07). So that it can be said that the higher or better the entrepreneurial orientation and creativity of an entrepreneur, the more business development will increase.
\end{abstract}

Keywords: Entrepreneurial Orientation, Creativity, Small Business Development

\section{Introduction}

The Small businesses are playing an important role in development and economic growth, not only in developing countries, but also in developed countries. Small businesses are very important in 
developed countries, not only because they absorb the most labor compared to large businesses, as in developing countries, but also their contribution to the formation or growth of gross domestic product (GDP) is greater than the contribution of large businesses, Tambunan (2012:32). The existence of small businesses is very helpful to the community, especially the lower middle class, because this small business is an independent business industry. Therefore, many small businesses experience obstacles both internal and external.

One of the factors identified influences the development of cooperative members' small businesses, namely entrepreneurial orientation. According to Mahmud and Bambang (2011:215), said that the development of a business is influenced by entrepreneurial orientation. Entrepreneurial orientation is a factor that contributes to improving business performance. The entrepreneurial orientation found in business organizations can determine the direction in which the competitive advantage will be focused. Entrepreneurial orientation is one of the key elements to gain competitive advantage and financial rewards. In general, with the increase in the number of companies that have an entrepreneurial orientation, they are generally able to make changes and react quickly to changes in a flexible and agile way.

The next factor identified that affects the development of cooperative members' small businesses, namely creativity. Entrepreneurs generally have the same nature, they are people who have the energy, the desire to be involved in innovative opportunities, the willingness to accept personal responsibility in realizing an event in the way they choose and the desire to achieve. Creativity is the ability possessed by humans to change something that already exists to be more interesting. Every entrepreneur is required to have a high spirit of creativity to create a product that is more attractive to consumers. With a high spirit of creativity, entrepreneurs can transform existing goods into more attractive items both in terms of shape and beauty. According to Fadiati \& Purwana (2011:125), creativity is the ability possessed by humans to change something that already exists to be more interesting. Every entrepreneur is required to have a high spirit of creativity to create a product that is more attractive to consumers. Widayatun (2006:122) said that creativity is an ability to solve problems, which gives individuals creating original / adaptive ideas with full use of functions to develop.

Lakon Nakukun Mosu Naroman Credit Union (CU Lanamona) was established on July 19, 2008. The number of CU Lanamona members at the end of December 2018 was 1561 members and CU Lanamona's assets were $\$ 951,900.89$. According to data from CU Lanamona members, the 
members who work as farmers are 656 people or $42 \%$, members who do business are 281 people or $18 \%$, members who work as civil servants are 390 people or $25 \%$, and members who are private a total of 234 people or $15 \%$.

Based on pre-research conducted by researchers through interviews with CU Lanamona, it is known that a number of 674 or $43 \%$ of the 1561 members who made loans. Of the 674 borrowers, $19 \%$ or a total of 130 people made productive loans or loans for business purposes, while other loans were intended for consumptive and emergency purposes. When compared with the status of the number of members with the title as business people (281 people), the number of business people who use credit services at CU Lanamona is $46 \%$. The implication of CU Lanamona regarding the development of small businesses is the need to develop an entrepreneurial soul and spirit, so there is always a spirit to develop new products or services that are in accordance with the needs and desires of customers.

The soul and spirit of entrepreneurship at CU Lanamona is still very low, marked by not many small business entrepreneurs in the small business center area in Maliana, particularly CU Lanamona members who make loans related to business orientation. This is evident from the low number of members making loans at CU Lanamona, which only $19 \%$ related to business orientation, which is attached in the following data:

Tabel 1.1 Type of Business running by Lanamona CU Members

\begin{tabular}{|l|l|l|l|}
\hline No & Business type & amount & Percentage \\
\hline 1 & Stall & 96 & $74 \%$ \\
\hline 2 & Vegetable Seller & 15 & $12 \%$ \\
\hline 3 & Sale dealer & 7 & $5 \%$ \\
\hline 4 & Tailor's Clothes & 4 & $3 \%$ \\
\hline 5 & Taxibike & 8 & $6 \%$ \\
\hline \multicolumn{2}{|l|}{ Total } & $\mathbf{1 3 0}$ & $\mathbf{1 0 0 \%}$ \\
\hline
\end{tabular}

The members who borrowed funds from business-oriented Lanamona CU totaled 130 people from a total of 1561 members with a loan fund of $\$ 35,801.00$ of CU Lanamona's total assets of $\$$ 951,900.89. From 130 people who made loans at CU Lanamona to increase their business capital, 
113 people or $87 \%$ experienced success, while the rest or $13 \%$ were less successful in their businesses.

Based on this background, the authors feel interested to study further or examine more deeply and conduct research with the title "The Effect of Entrepreneurial Orientation and Creativity on the Development of Small Business Members of the CU Lanamona".

To reinforce the reasons for choosing a research location, the authors chose CU Lanamona, because it has more than one thousand members and moves across municipalities, meaning that it has branches in other municipalities, namely in Dili and Ermera municipalities. In addition, CU Lanamona was initiated and chaired by a woman, which is very much in line with the current world movement that focuses on gender issues.

The objectives of this study are, to analyze and describe; 1). The partial effect of entrepreneurial orientation on the development of small businesses in the CU Lanamona. 2). The effect of partial creativity on the development of small business cooperative members of the CU Lanamona. and 3). The simultaneous influence, entrepreneurial orientation and creativity on the development of small businesses in the CU Lanamona.

\section{Previous theories or research}

A). Entrepreneurial Orientation and Small Business Development.

1. Based on research conducted by Sari (2016) that examines the effect of entrepreneurial orientation on the performance of Makassar City SMEs, with the results of the study showing that there is an influence between entrepreneurial orientation (simultaneous testing) on the performance of Makassar City SMEs, there is an influence on entrepreneurial orientation (test partially) on the performance of Makassar City SMEs.

2. Another study conducted by Fauni (2017) in a thesis that examines the effect of entrepreneurial orientation on the performance of micro small and medium sized convection businesses in Kudus Regency with the results of the study showed that there was a positive and significant effect on entrepreneurial orientation on business performance both directly and indirectly through competitive advantage with a total influence of $21.70 \%$.

3. Other research conducted by Toyib (2017) that examines the effect of entrepreneurial orientation on the performance of small and medium-sized businesses with the results of 
the study shows that entrepreneurial orientation has a significant influence on the performance of small and medium-sized businesses in Manokwari Regency.

4. Subsequent research conducted by Wulaningtyas and Widiartanto (2017) who examined the effect of entrepreneurial orientation on the performance of small and medium industries (Study on IKM Furniture in the City of Semarang) with the results of the study showed that there was a positive and significant effect between entrepreneurial orientation on business performance IKM wood furniture in the city of Semarang.

5. Research conducted by Palit, Monika Kristanti and Debora Anne Yang Aysia (2015) who examined the effect of entrepreneurial orientation on improving the performance of the Indonesian Traditional Culinary Depot in Surabaya with the results of the study showed that entrepreneurial orientation significantly affected Depot performance.

\section{B). Relationship of Creativity with Small Business Development}

1. Based on research conducted by Purwana, et al (2017) which examines the influence of creativity on business development in small and medium-sized businesses in the Pulogadung East Jakarta small industrial village, with the results of the study showing that there is a positive and significant influence between creativity on business development small and medium enterprises in Pulogadung East Jakarta small industrial village.

2. Another study conducted by Mardiah (2017) who examined the influence of the influence of creativity on entrepreneurship in the UMKM Food Court at Cikarang Wholesale Center with the results of research that creativity has a partial effect on entrepreneurship. There is a significant relationship between creativity and small business development. With creativity can have an impact on small business development.

C). Relationship between Business Orientation and Creativity Against Development Small business.

The first factor identified affects the development of cooperative members' small businesses namely entrepreneurial orientation. According to Mahmud and Bambang (2011:215) said if the development of a business is influenced by entrepreneurial orientation. Entrepreneurial orientation is a factor that contributes to improving business performance.

The second factor identified influences the development of cooperative members' small businesses namely creativity. Entrepreneurs generally have the same nature, they are people who have the 
energy, the desire to be involved in innovative opportunities, the willingness to accept personal responsibility in realizing an event in the way they choose and the desire to achieve.

\section{RESEARCH METHODOLOGY}

This research is included in survey research, which is a study that takes a sample from a population and uses questionnaires as a primary data collection tool. This survey research is for the purpose of providing an explanation of the causal relationship between variables through hypothesis testing (Singa Ribun, 1989).

The object of the study was a member of the CU Lanamona. The reason for choosing this research object is because; (1) CU Lanamona has not done any research on this title. (2) The company is willing to provide data / information needed for the purpose of this research.

The population in this study were all businesses that received loans from CU Lanamona, totaling 130 businesses. The sample in this study was that all members of the population were sampled. Thus it is known that the sampling technique used in this study is saturated samples. The population as well as the sample in this study amounted to 130 businesses.

The type of data collected and presented by the writer in this thesis are qualitative and quantitative data. The data obtained and set forth in this thesis come from primary and secondary sources. For data collection in the field, the author combines several data collection techniques, namely 1) Questionnaire, 2) Interview and 3) Documentation.

\section{Hypothesis in this study}

Companies that have a strong entrepreneurial orientation will have the ability to innovate more strongly than other companies, will be more willing to take risks, and not just stick to past strategies. In a dynamic environment, entrepreneurial orientation is clearly very important for the survival of the company. Fauni (2017) in his research concluded that entrepreneurial orientation had a positive and significant effect on business performance. Based on the description, the hypothesis can be formulated as follows:

H1: entrepreneurial orientation has a positive and significant effect on the development of small businesses in the CU Lanamona.

Creativity is the ability possessed by humans to change something that already exists to be more interesting. Every entrepreneur is required to have a high spirit of creativity to create a product that is more attractive to consumers. Hadiyati (2011) in his research concluded that creativity has 
a positive and significant effect on small business entrepreneurship. Based on the description, the hypothesis can be formulated as follows:

$\mathrm{H} 2$ : creativity has a positive and significant effect on the development of small businesses in the CU Lanamona.

The existence of small businesses is very helpful to the community, especially the lower middle class, because this small business is an independent business industry. Entrepreneurial orientation and the ability to be creative are a number of factors that influence the development of a cooperative's small business. ROFIUDDIN (2016) in his research concluded that Entrepreneurship and Creativity Orientation simultaneously had a significant effect on Business Performance. Based on the description, the hypothesis can be formulated as follows:

H3: entrepreneurial orientation and creativity have a positive and significant effect on the development of small businesses in the CU Lanamona.

\section{RESULTS AND DISCUSSION}

\section{Multiple Linear Regression Analysis}

To determine the effect of entrepreneurial orientation and creativity on the development of small businesses can be known by using multiple linear regression analysis, using SPSS 21 and the calculation of the results of multiple linear regression is shown in the following Table 5.10:

Table 5.10 Results of Multiple Linear Regression Analysis

\begin{tabular}{|c|c|c|c|c|c|c|}
\hline \multirow{2}{*}{\multicolumn{2}{|c|}{ Model }} & \multicolumn{2}{|c|}{ Unstandardized Coefficients } & \multirow{2}{*}{\begin{tabular}{|l} 
Standardized \\
Coefficients
\end{tabular}} & \multirow[b]{2}{*}{$\mathrm{t}$} & \multirow[b]{2}{*}{ Sig. } \\
\hline & & B & Std. Error & & & \\
\hline \multirow[t]{3}{*}{1} & (Constant) & 13.978 & 2.858 & & 4.891 & .000 \\
\hline & $\begin{array}{l}\text { Entrepreneurial } \\
\text { Orientation }\end{array}$ & .178 & .064 & .267 & 2.775 & .006 \\
\hline & Creativity & .214 & .055 & .371 & 3.857 & .000 \\
\hline \multicolumn{4}{|c|}{ a. Dependent Variable: Small Business Development } & & & \\
\hline
\end{tabular}

The multiple linear regression equation can be seen from table 5.10 based on the analysis with the SPSS 21 program, the results of the multiple linear regression equation are as follows: $\mathrm{Y}=13,978+0,178 \mathrm{X} 1+0,214 \mathrm{X} 2$ 
The regression equation has the following meanings:

1. Constants $=13,798$

If the entrepreneurship and creativity orientation variable is constant $=0$ (unchanged), then the magnitude of the change in organizational commitment variable is 13,798

2. Variable coefficient $\mathrm{X} 1=0.178$

If the entrepreneurial orientation variable increases by one point (unit), while creativity remains, it will cause an increase in the development of small businesses by 0.178

3. Variable coefficient $\mathrm{X} 2=0.214$

If the creativity variable increases by one point (unit), while the entrepreneurial orientation is permanent, it will cause an increase in business performance of 0.214.

\section{Coefficient of Determination}

Determination analysis is used to measure how much influence the independent variable has on the dependent variable that can be seen in the following table:

Table 5.11 Results of the Determination Coefficient Analysis

\begin{tabular}{|l|r|r|r|r|}
\hline \multicolumn{3}{|l|}{ Model Summary } \\
\hline Model & R & R Square & Adjusted R Square & Std. Error of the Estimate \\
\hline 1 & $.583^{\mathrm{a}}$ & .340 & .330 & 2.859 \\
\hline \multicolumn{7}{|l|}{ a. Predictors: (Constant), Creativity, Entrepreneurial Orientation } \\
\hline \multicolumn{2}{|l|}{ b. Dependent Variable: Small Business Development } \\
\hline
\end{tabular}

Based on Table 5.11 it can be seen that the value of R Square or commonly referred to as the coefficient of determination obtained is 0.538 , meaning that $53.8 \%$ of variations occur in the high and low development of small businesses due to entrepreneurial orientation variables (X1) and creativity (X2) while the remaining $46.2 \%$ explained by other variables not taken into account in this study, with the standard error or Standard Error of Estimate, $\mathrm{Se}=2,859$.

\section{Hypothesis Testing}

\section{T Test (Partial Test)}

Hypothesis 1 and 2 tests were conducted to test each of the $\mathrm{X}$ variables with the test. 
Table 5.12 Hypothesis Test Results (t Test)

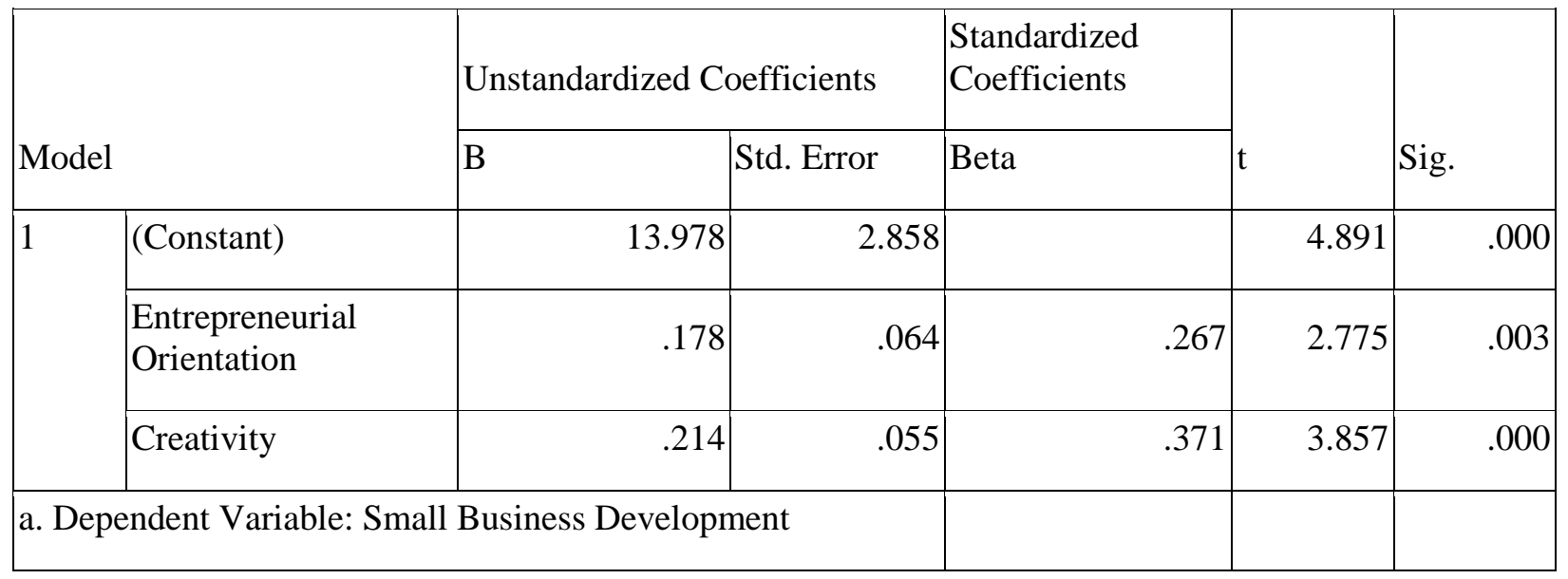

Hypothesis 1 - The effect of entrepreneurial orientation on the development of small businesses Testing using SPSS version 21, entrepreneurial orientation variable (X1) was obtained $t$-count of 2.775 with a significant level of 0.04 while the value of the $t$-table was $1.97810(\mathrm{df}=130-2=128)$. Because the significant value of 0.03 is smaller than alpha $0.05(\rho<\alpha)$ and the t-count is greater than $t$-table $(2.775>1.97810)$, this means that the entrepreneurial orientation variable has a positive and partially significant effect on the development of small businesses. Therefore, the better the entrepreneurial orientation that is owned by entrepreneurs, the business development will increase. Hypothesis 2 - Effect of creativity on small business development

Tests using SPSS version 21 , creativity variable (X2) obtained t-count of 3,857 with a significant level of 0,000 while the value $t$-table is $1,97810(\mathrm{df}=130-2=128)$. Because the significant value of 0,000 is smaller than alpha $0.05(\rho<\alpha)$ and the $t$-count is greater than $t_{\text {table }}(3,857>1,97810)$, this means that the creativity variable has a positive and partially significant effect on the development of small businesses. Therefore, the higher the creativity that is carried out by entrepreneurs, the business development will increase.

\section{F Test (Simultaneous Test) - Hypothesis 3}

For the hypothesis 3 test used the $\mathrm{F}$ test with decision criteria $\mathrm{Ha}$ is accepted if $\mathrm{F}$-count is greater than $\mathrm{F}_{\text {-table }}\left(\mathrm{F}_{\text {-count }}>\mathrm{F}_{\text {-table }}\right)$ or significant level $(\mathrm{p})$ is smaller than alpha $(\mathrm{p}<\mathrm{a})$ and vice versa $\mathrm{Ha}$ is rejected and $\mathrm{Ho}$ is accepted if $\mathrm{F}_{\text {-count }}<\mathrm{F}_{\text {-table }}$ or $\mathrm{p}>\mathrm{a}$. To find the $\mathrm{F}_{\text {-count, }}$, it can be seen from the results of the SPSS 21 analysis (Anova Table) below: 
Table 5.14 F Test Results (Simultaneous Test)

\begin{tabular}{|l|l|l|r|r|r|r|}
\hline \multicolumn{7}{|l|}{ ANOVA $^{\text {b }}$} \\
\hline \multicolumn{2}{|l|}{ Model } & $\begin{array}{l}\text { Sum of } \\
\text { Squares }\end{array}$ & df & Mean Square & F & Sig. \\
\hline 1 & Regression & 535.208 & 2 & 267.604 & 32.746 & $.000^{\mathrm{a}}$ \\
\hline & Residual & 1037.868 & 127 & 8.172 & & \\
\cline { 2 - 7 } & Total & 1573.077 & 129 & & & \\
\hline
\end{tabular}

Based on the results of calculations with the SPSS 21 program (ANOVA Table) obtained $\mathrm{F}=$ 32,746 and distribution table F0.05: 2: $128=3.07$. Because $F=32,746>F 0.05: 2: 128=3.07$ with a significant level of 0,000 and $\alpha=0.05$, it can be concluded that the entrepreneurial orientation and creativity variables simultaneously have a positive and significant effect on the development of small businesses.

\section{Effect of Entrepreneurial Orientation on Small Business Development}

Based on the results of hypothesis testing conducted, it was found that the entrepreneurial orientation variable had a positive and partially significant effect on the development of small businesses. This is evidenced by the value of $\mathrm{t}$-count 2.775 greater than $\mathrm{t}$-table 1.97810 . Thus the hypothesis in this study was accepted and the formulation of the problem can be answered.

This study is in line with research conducted by Fauni (2017) in a thesis that examines the effect of entrepreneurial orientation on the performance of small and medium sized micro convection businesses in Kudus Regency with the results of the study showing that there is a positive and significant effect on entrepreneurial orientation on business performance.

These results suggest that entrepreneurial orientation is a factor that plays an important role in determining the level of improvement of small business development. The higher entrepreneurial orientation, will encourage the higher development of small businesses. Conversely, if entrepreneurship orientation is low, business development will also experience a decline. 
Based on the results of hypothesis testing conducted, it was found that the creativity variable had a positive and partially significant effect on the development of small businesses. Therefore, the higher the creativity that is carried out by entrepreneurs, the business development will increase. This is evidenced by the value of $t$-count (3.857) is greater than $t$-table (1.97810). Thus the hypothesis in this study was accepted and the formulation of the problem can be answered.

This study is in line with research conducted by Purwana (2017) which examines the effect of creativity on business development in small and medium enterprises in the Pulogadung East Jakarta small industrial village, with the results of the study showing that there is a positive and significant effect between creativity on small business development and middle in the small industrial village of Pulogadung, East Jakarta.

\section{Effects of Entrepreneurial Orientation and Creativity on Small Business Development}

Based on the results of simultaneous hypothesis testing ( $F$ test) that has been done shows that the entrepreneurial orientation and creativity variables simultaneously have a positive and significant effect on the development of small businesses. This is evidenced by the calculated F-count $(32,746)$ greater than $\mathrm{F}_{\text {-table }}$ (3.07). So it can be said that the higher or better the entrepreneurial orientation and creativity of an entrepreneur, the more business development will increase.

\section{CONCLUSION}

Based on the results of tests and explanations made by researchers about the effect of entrepreneurial orientation and creativity on the development of small businesses, the authors can draw the following conclusions:

First; Entrepreneurial orientation has a positive and partially significant effect on the development of small businesses. The better entrepreneurial orientation owned by CU Lanamona members, the development of their businesses will increase.

Second; Creativity is a positive and partially significant effect on the development of small businesses. In this case, the higher entrepreneurial creativity of CU Lanamona members, the business development will increase.

Third; Entrepreneurial orientation and creativity simultaneously have positive and significant effects on the development of small businesses. In this case, it is known that the better entrepreneurial orientation and the higher entrepreneurial creativity of CU Lanamona members, the development of their businesses will increase. 


\section{Implications}

Based on the research model developed in this study, it can strengthen theoretical concepts and provide empirical support for previous research.

The theoretical implications are: 1). Entrepreneurial orientation variables have a positive and partially significant effect on the development of small businesses. The results of this study empirically reinforce previous research conducted by Fauni (2017). 2). The variable of creativity has a positive and partially significant effect on the development of small businesses. The results of the study empirically reinforce previous research conducted by Purwana (2017).

The practical implications for improving business development, it is necessary to maximize the entrepreneurial orientation and creativity of entrepreneurs who get business loan funds from CU Lanamona.

\section{REFERENCES}

Afuah, Allan. 2004. Business Model: A Strategic Management Approach. New York; McGraw Hill

Alonadus. 2015. Pengaruh motivasi terhadap Kinerja Karyawan pada Perusahaan Daerah Air Minum (PDAM) Kabupaten Kupang.

Arta Adi Kusuma. 2013. Pengaruh Motivasi dan lingkungan kerja terhadap kinerja karyawan Hotel Muria Semarang.

Basuki dan Susilowati. 2005. Dampak kepemimpinan dan lingkungan kerja terhadap semangat kerja. Jurnal JRBI, Vol. 1 No. 1, Januari.

Burhanudin. 2012. Analisis pengaruh kepuasan kerja dan motivasi terhadap kinerja karyawan dengan (studi pada PT. Bank Mandiri Makasar).

Dalimunthe, Ritha R. Pengaruh Karakteristik Individu, Kewirausahaan, Gaya Kepemimpinan Terhadap Kemampuan Usaha Serta Keberhasilan Usaha Industri Kecil Tenun dan Bordir di Sumatera Utara, Sumatera Barat dan Riau. Universitas Airlangga. Perpustakaan Ekonomi Universitas Sumatera Utara. 2002 (tidak dipublikasikan)

David, Fred R. 2011. Strategic Management. Buku 1. Edisi 12. Jakarta; Ghalia Indonesia.

Fadiati, Ari dan Dedi Purwana. 2011. Menjadi Wirausaha Sukses. Bandung; PT. Remaja Posdakarya. 
Ghozali. 2009. Aplikasi Analisis Multivariate dengan proses SPSS. Semarang. UNDP.

Grifin. 2003. Manajemen. Erlangga, Jakarta.

Hadinoto, Soetanto dan Retnadi Djoko. 2007. Micro Credit Challenge. Jakarta; Media Komputindo.

Hafsah, M. Jafar. 2004. Upaya Pengembangan Usaha Kecil dan Menengah (UKM). Infokop Nomor 25 Tahun XX.

Hasan. 2012. Kamus Besar Bahasa Indonesia. Edisi 4. Jakarta: Bakti Pustaka.

Hasibuan S.P. 2010. Manajemen Sumber Daya Manusia dan kunci Keberhasilan. Bumi Aksara.

Hasibuan S.P. 2002. Manajemen Sumber Daya Manusia. Edisi Revisi Bumi Aksara.

Hurlock, E.B. 1993. Psikologi Perkembangan: suatu pendekatan sepanjang rentang kehidupan (Edisi Kelima). Jakarta; Erlangga.

Kadarisman. 2012. Manajemen Pengembangan Sumber Daya Manusia. Rajawali. Pers: Jakarta.

Kanis Hasibuan, Malayu S.P. 2013. Manajemen Sumber Daya Manusia. Jakarta: PT. Bumi Aksara.

Kasmir. 2006. Manajemen Peningkatan Kinerja. Jakarta: PT. Bumi Aksara.

Kotler, Philip. 1996. Manajemen Pemasaran: Marketing Management 9e. Jakarta; PT. Prenhallindo

Lumpkin, G., \& Dess, G. (1996). Clarifying the Entrepreneurial Orientation Construct and Linking it to Performance. Academy of Management Review, 21 (1).

Manulang. 2005. Manajemn Sumber Daya Manusia. Edisi ke 2, Cetakan pertama, BPFE Yogyakarta.

Marwansyah. 2010. Manajemen Sumber Daya Manusia. Edisi kedua. Alfabeta. Bandung.

Masrudin, Yudi. Pengaruh Spirit of Entrepreneur Terhadap Keberhasilan Usaha Pada Usaha Makanan di Jl. Dr. Mansyur Medan. Perpustakaan Ekonomi Universitas Sumatera Utara. 2007 (tidak dipublikasikan)

Mathis dan Jackson. 2002. Manajemen Sumber Daya Manusia. Jakarta: Salemba Empat.

Mathis R.L dan Jackson J.H. 2006. Manajemen Sumber Daya Manusia-Salemba Empat, Edisi kesepuluh, Jakarta.

Matondang, Indra Hakim. Analisis Faktor-Faktor Yang Mendorong Wirausahawan Memulai Usaha Kecil (Studi Kasus Pada Gerai Penjualan Pulsa Handphone di Sepanjang Jl. Letda Sujono Medan). Perpustakaan Ekonomi Universitas Sumatera Utara. 2006 (tidak dipublikasikan) 
Miller, D. 1983. The Correlates of Entrepreneurship in three types of Firms. Management Science, Vol 29(7):770-791.

Moekijat. 2002. Dasar-dasar Administrasi dan Manajemen Perusahaan. Bandung Mandar maju.

Munandar, S.C. Utami. 1999. Kreativitas dan Keberbakatan. Jakarta; Gramedia Pustaka Utama

Nasution, Darma Putra, dkk. Pengembangan Wira Usaha Baru, Yayasan Humaniora \& Asian

Community Trust (ACT), Medan. 2001

Nasution. 2003. Metode Research. Jakarta PT. Bumi Aksara.

Nasution. 2003. Metode Research. Jakarta: PT. Bumi Aksara.

Nitisemito, Alex S. 1995. Manajemen Personalia. Cetakan keenam.Jakarta:

Nitisemito, Alex, S. 2001. Manajemen Personalia: Manajemen Sumber Daya Manusia. Edisi kelima, Ghalia Indonesia, Jakarta.

Nugroho, Setiadi J. 2003. Perilaku Konsumen: konsep dan implikasi untuk strategi dan penelitian bisnis pemasaran. Jakarta; Prenada media

Prabu Mangkunegara Anwar. 2008. Manajemen Sumber Daya Manusia perusahaan. Edisi dari Teori ke Praktik, Bandung: Alfabeta.

Putra, Rizky. Pengaruh Kepemimpinan Terhadap Kinerja Karyawan Pada PT. Bank Sumut Cabang Utama Medan. Perpustakaan Ekonomi Universitas Sumatera Utara. 2008 (tidak dipublikasikan)

Rahmad. 2016. Pengaruh Lingkungan Kerja Terhadap semangat kerja karyawan pada X2 Family Karaoke Home Teater dan Resto Kupang.

Reni, Akbar-Hawadi. 2001. Psikologi Perkembangan anak: Mengenal Sifat, Bakat, dan Kemampuan Anak. Jakarta: Gramedia.

Rivai, Vethzai \& Basri. 2005. Performance Appraisal: sistem ysng tepat untuk menilai kinerja dan meningkatkan daya saing perusahaan, Jakarta: PT. Raja Grafindo Persada.

Rivai. 2004. Manajemen Sumber Daya Manusia, Perusahaan. Bandung: Remaja Rosdakaya.

Riyanti Dwi dan Benedicta Prihatin. 2003. Kewirausahaan dari sudut Pandang Psikologi Kepribadian. Jakarta; PT. Grasindo

Robbins dan judgle. 2007. Perilaku Organisasi. Terj. Diana Angelica. Jakarta: Salemba Empat (pp. 230-233).

Robbins, S.P. 2006. Organizational, newJersey: Pretince Hall.

Robbins. 2003. Prinsip-prinsip perilaku organisasi. Edisi kelima. Erlangga. Jakarta. 
Rogers, Everett M. 2003. Diffusion of Innovation. New York; The Free Press

Sadoko Isono dan Heriyadi, 2001. Pengembangan Usaha Kecil (Pemihakan Setengah Hati). Bandung; Yayasan Aka Tiga

Scarborough, Norman M. dan Thomas, W. Zimmerer. 1993. Effective Small Business Management. Macmillan Publishing Company. Jakarta.

Sedarmayanti. 2001. Dasar-dasar pengetahuan tentang manajemen perkantoran. Bandung: Mandar Maju.

Shabib, Nurhalim. 2002. Pembinaan Kreativitas Menuju Era Global. Bandung; PT. Alumni

Siagian. 2004. Manajemen Sumber Daya Manusia. Jakarta: abaumi Aksara.

Simamora. 2002. Manajemen Sumber Daya Manusia. STIE YKPN. Semarang.

Singaribun dan Effendi. 1989. Metode Penelitian Survey. Jakarta; LP2ES

Sondang Siagian. 2003. Manajemen Sumber Daya Manusia, Bumi Aksara. Yogyakarta.

Sugiyono. 2010. Metode penelitian Bisnis (Pendekatan Kuantitaif, Kualitatif dan R\&D). Bandung; Alfabeta

Sugiyono. 2014. Metode Penelitian Pendidikan Pendekatan Kuntitatif kualitatif dan R\&D. Bandung; Alfabeta.

Suryana. 2003. Kewirausahaan: Pedoman Praktis, Kiat dan proses menuju sukses (edisi revisi). Jakarta; Salemba Empat.

Tambunan, Tulus. 2012. Usaha Mikro Kecil dan Menengah di Indonesia: Isu-isu Penting. Jakarta; LP3ES

Widayatun, T. 2006. Ilmu Perilaku. Jakarta; CV. Agung Seto 